\title{
KRYTYKA KSZTALCENIA MORALNO-ETYCZNEGO JAKO POZYTYWNY MOMENT WYCHOWANIA CZŁOWIEKA W HUMANISTYCZNEJ KONCEPCJI BOGDANA SUCHODOLSKIEGO
}

Streszczenie: W wydanej w 1936 roku książce Wychowanie moralno-społeczne Bogdan Suchodolski poddaje głębokiej krytyce ideę i praktykę tradycyjnie prowadzonego wychowania w zakresie moralności. Rozwój społeczno-moralny dotyczy całej osobowości człowieka, która wzrasta i zmienia się przez całe życie. W związku z tym jej kształcenie ani nie może ograniczać się do jakiegoś „czasu nauki” w odróżnieniu od „czasu życia”, ani nie odbywa się w oderwaniu od przemian otoczenia jednostki, zarówno w wymiarze bliskim, jak i odległym. W tym kontekście Suchodolski wykazuje nieprzydatność kształcenia przygotowującego, podkreślając znaczenie wychowania uczestniczącego i reformującego. Tak więc wychowanie społeczno-moralne polegać winno na takim kształceniu osobowości, aby potrafiła ona osiągać samodzielność w samowychowaniu i poprzez rozwój umiejętności życia wewnętrznego, społecznego i kulturalnego. Odbywa się to nie intelektualistycznie, lecz integralnie, na mocy przewyższania poziomu dotychczasowego rozwoju przez miłość i twórczość w budowaniu wspólnoty. Decyduje o tym charakter pracy jednostki, prowadzący do wewnętrznego rozwoju osobowości i uspołeczniającego uczestnictwa w otaczającej rzeczywistości.

Słowa kluczowe: osobowość, wychowanie społeczno-moralne jako samowychowanie humanistyczne, miłość, praca ludzka, wymiana przeżyć, wspólnota poprzez twórcze uczestnictwo, selekcja i kontemplacja, wolność moralna.

\section{Wprowadzenie}

Książka Bogdana Suchodolskiego pt. Wychowanie moralno-społeczne ukazała się w roku 1936 w Warszawie jako odbitka zeszytu 14 pierwszego tomu Encyklopedii wychowania, wydanej pod redakcją S. Łempickiego, W. Gottlieba, B. Suchodolskiego i J. Włodarskiego. Zeszyt ten wydano prawdopodobnie dwa lata wcześniej - w roku 1934 .

Niniejsze opracowanie dotyczy stanowiska, jakie wobec problematyki moralnej w pedagogice zajął Suchodolski, niebawem, gdyż od października 1936 roku, 
naczelnik Wydziału Naukowo-Programowego MWRiOP. Stanowisko to jest szczególne. Suchodolski nie podziela bowiem przekonań charakterystycznych dla panującego ówcześnie obozu politycznego. Wyraża natomiast postawę zaprezentowaną w kluczowym tekście pt. Nowy humanizm (1935). W związku z tym zaprezentowane tu opracowanie ma charakter szczególny. Jego autor całkowicie zrezygnował z prezentacji „zewnętrznego” materiału krytycznego, koncentrując się wyłącznie na toku myśli samego Suchodolskiego.

Wiemy, co to był za okres w życiu Polski, Europy i całego świata. Nie było jeszcze Monachium, Anschlussu Austrii i rozbioru Czechosłowacji. Faszyzm uznawany był za jedną z wielu doktryn politycznych mających swoje pozytywne - jak sądzono - wymiary społeczne i pedagogiczne. Ale Niemcami rządził już Hitler, uprawiano bezwzględną walkę polityczną, trwały prześladowania Żydów, rozwijał się złowrogi nazizm.

Złowieszczy rozwój tych wszystkich czynników bezbłędnie dostrzegał i opisywał Suchodolski. Książka z 1936 roku podejmuje pozytywną krytykę przewagi wychowania wspólnotowego nad indywidualnym. Suchodolski - mając na uwadze rozbicie substancjalności polskiej w okresie zaborów i wspierając wysiłki młodego państwa polskiego po 123 latach niewoli - wysoko ceni nową wówczas ideę wychowania przez zbiorowy wysiłek wspólnoty, w przeciwieństwie do tych opcji pedagogicznych, których efektem jest osłabiający tożsamość narodową i siłę państwa indywidualizm, właściwy dla nurtów liberalistycznych. Ale w koncepcji Suchodolskiego wspólnota nie jest wyłącznym i ostatecznym celem działalności pedagogicznej. Celem takiej działalności jest powstawanie osobowości i jej humanistyczny rozwój. Oznacza to rozwój struktury ludzkiej bogatej zarówno w cechy indywidualne, jak i wspólnotowe, charakteryzujące człowieka kulturalnie uspołecznionego. Mówi o tym bodajże najwybitniejsza praca Suchodolskiego z tamtych czasów - Uspołecznienie kultury, przygotowywana równolegle z Wychowaniem moralno-społecznym, a wydana niebawem, gdyż już w roku 1937. Niniejszy artykuł - niemal jak pastisz - śledzi dokładnie wywód myśli Suchodolskiego, utrzymując również styl jego narracji. Liczne cytowania stanowią integralną składową konstrukcji tekstu.

Uważna analiza niniejszego rozważania może prowadzić do wniosku, że koncepcja wychowania społeczno-moralnego, jaką zaprezentował Suchodolski, znacząco wymyka się zarówno klasyfikacjom personalistycznym, jak i kolektywistycznym w każdym znaczeniu tego terminu: „zarówno doktryna gromady, jak i doktryna jednostki są wyrazem ograniczającym pojmowania człowieka" (Suchodolski 1936, s. 64).

\section{Wychowanie i osobowość}

Wychowanie jest jednolitym i niepodzielnym procesem obejmującym całą osobowość ludzką. W przeciwnym razie staje się powierzchowną tresurą i złudzeniem. Jeżeli zatem chcemy wychowywać człowieka - religijnie, moralnie, intelektualnie, 
społecznie, estetycznie, fizycznie, zawodowo itd. - musimy zawsze mieć na uwadze całego człowieka. Stąd i prawdziwa działalność wychowawcza jest zawsze pewną całością ${ }^{1}$. Całość tę Suchodolski określa mianem „wychowania społecznego” (Suchodolski 1936, s. 3). Dotyczy to samej jednostki, ale i całokształtu jej uwarunkowań zarówno dotychczasowych, jak i prospektywnych. Dlatego człowieka ogólnego należy traktować jako „zespół dążeń i wartości uwarunkowany tym, czym w danej sytuacji człowiek istotnie jest" (Suchodolski 1936, s. 4)². Wychodząc z takich założeń, Suchodolski stwierdza, iż brak wychowania moralnego oznacza „brak ludzi umiejących zająć właściwą postawę w tej zmiennej cywilizacji, ludzi, którzy by nie powiększali chaosu złą wolą lub nieświadomością" (Suchodolski 1936, s. 7). To wyraźnie humanistyczne stanowisko wyraża mocny pogląd, że sposób życia człowieka jako jednostki ludzkiej stanowi centralną kategorię przebudowy społecznej zarówno w sensie jej rozumienia, jak i jej samej. Podkreśla więc Suchodolski znaczenie analizy czynników zespalających świat moralny i świat społeczny, dążącej do wykazania, iż „istota wychowania polega na równoczesnym przekształcaniu środowiska i psychiki" (Suchodolski 1936, s. 15) ${ }^{3}$. Oczywistym więc jest, że osobowość, zresztą integralnie z dynamicznym rozumieniem człowieka, nie istnieje poza konkretnym procesem uczestnictwa i udziałów w życiu. „Opieranie się na jakiejś idei obowiązku, ustalonej z góry i raz na zawsze, jest rezygnacją z żywego uczestniczenia w procesie przemian" (Suchodolski 1936, s. 16) - twierdzi Bogdan Suchodolski Stąd mówienie o wychowaniu moralno-społecznym, prowadzenie intelektualistycznej edukacji na jego temat ma $\mathrm{z}$ natury rzeczy pusty charakter. Z tego też względu definicja ogólna takiego wychowania jest myląca i po prostu niemożliwa. Tylko z ludzkich dążeń można to wychowanie - jako samowychowanie - wywieść. Ważne jest głębokie uświadomienie sobie, iż Suchodolski tak właśnie rozumiał wychowanie, z tą uwagą, że owo samowychowanie mieści w sobie również rzetelny kontakt z wieloma czynnikami znaczącymi, w tym z osobami mającymi niezaprzeczalny wpływ wychowawczy na samoedukujący się podmiot.

Za Irvingiem Babbittem Suchodolski przekonuje, że w człowieku są dwie jaźnie i dwie wole: niższa i wyższa. Jaźń niższa pożąda wiedzy, rozkoszy i władzy w ilości nieograniczonej. Wyższa jest źródłem powściągów, dzięki którym dokonuje się zharmonizowanie istnienia ludzkiego, co prowadzi do stopniowej harmonizacji ludzkiej istoty. Ważną, wręcz podstawową rolę, odgrywa tu czynnik czci i pokory wobec wartości. Powściągi te nie mogą być wyłącznie intelektualne - musi być w nich element chęci. Wola zaś, aby działała, winna być poruszona przez wyobraźnię. Budować zaś życie można tak, żeby szukanie wartości przenosić z płaszczyzny

${ }^{1}$ Wszystkie fragmenty pisane pogrubionym tekstem, z wyjątkiem tych, których dokonał sam B. Suchodolski, pochodzą od autora niniejszego artykułu.

2 B. Suchodolski zawsze twierdził, że człowiek jest istotą niepowtarzalną w warunkach zmiennej cywilizacji i w różnych kulturach.

${ }_{3}^{3}$ Problematykę tę szczegółowo omówił B. Suchodolski w artykule Nowy humanizm (1935a). 
niższej na wyższą. Teorii tej nie można uzasadniać tak jak Francis Bacon i Nicolo Macchiavelli, Anthony Ashley Shaftesbury i Jean Jacques Rousseau. U tych myślicieli walka dobra i zła została przesunięta $z$ duszy jednostek w świat społeczny i miała być tam rozegrana zwycięsko dzięki nauce i organizacji. Ale rzeczywistość zadała kłam tej teorii: chaos powstaje coraz większy. Euroamerykańskie społeczeństwo popadło w moralną bierność, równocześnie wierząc głęboko w postęp, który ma się dokonywać dzięki prawu natury. „Ale w rzeczywistości naturalny pęd wiedzie do barbarzyństwa” (Suchodolski 1936, s. 18). „Barbarzyństwo jest nieustającą groźbą dla cywilizacji” (Suchodolski 1936). Humanizm w tym względzie mocno ukazuje różnicę pomiędzy naturalistycznym a moralnym rozumieniem normy postępowania: „Między normą postępowania opartą na prawie przyrody a normą postępowania opartą na wartościach moralnych zachodzi zasadnicza różnica, i ucząc się posłuszeństwa wobec pierwszej, nie nabieramy wcale umiejętności słuchania drugiej" (Suchodolski 1936, s. 20). Drogą do tak pojętej dyscypliny nie jest przede wszystkim żaden przymus zewnętrzny, ale budzenie zainteresowań i zamiłowań. W ten sposób rozwój uczuciowy i intelektualny staje się wyrazem ludzkiej moralności. Wola bowiem nie jest odrębna od konkretnych postanowień i postępowań, a najlepszą szkołą dyscypliny jest pełnia życia. Dlatego też, choć odczuwanie i uznawanie każdego autorytetu zawsze wiąże się z poczuciem pewnej niższości i uległości wobec tego, co jest wyższe, mądrzejsze, lepsze itp. - to nie musi krępować, może podnosić. A ma siłę podnoszącą wówczas, gdy zetknięcie z czymś wyższym stanowi większą moc aniżeli fakt uzależnienia.

Ludzka, pełna postawa wobec życia, skutecznie przezwycięża wszelkie nastawienia roszczeniowe. W przeciwnym razie wytwarzające się „uczucia pożądliwości rozbudzają [...] instynkty posiadania, a współdziałanie nabiera charakteru zdobywczego" (Suchodolski 1936, s. 24). Stanowi to podstawowy czynnik pogłębiających się zróżnicowań społecznych o wyraźnie negatywnym charakterze. Brak „możliwie pełnego kształcenia młodzieży we wszystkich zakresach życia [...] prowadzi [...] do krytyki szkoły jako instytucji wychowawczej" (Suchodolski 1936, s. 23).

\section{Miłość i twórczość}

Tylko wtedy życie ma sens niesprowadzający się wyłącznie do wymiaru subiektywnego. W tak prowadzonym życiu humanistycznie wartościowe istnienie wewnętrzne w istotny sposób łączy się z wymiarem humanistycznym w kulturze obiektywnej. Najistotniejszą funkcję pełni w tym procesie osobowość, albowiem pisze Suchodolski - „im mniejszym wycinkiem naszej osobowości stykamy się z innymi ludźmi, tym łatwiej stosunki te nabierają cech rzeczowych i tym dalsze są od ideału wychowawczego” (Suchodolski 1936, s. 25). I konkluduje: „stosunki między ludźmi mają angażować całą osobowość i kierowane być mają na potrzebę współżycia, a nie korzyści. Współżycie zaś możliwe jest tam tylko, gdzie istnieje miłość" (Suchodolski 1936). 
Suchodolski krytykuje ujmowanie rzeczywistości poprzez środki i cele, o ile te ostatnie mają $\mathrm{w}$ istocie charakter przyjemności lub utylitarnej korzyści. To przeczy określaniu sensu przez miłość i dezorganizuje życie człowieka, pozbawia bowiem jego treści wartości samoistnych, autonomicznych. Przez to też niweczy wolność człowieka. Aby jednak miłość mogła stanowić konstytutywny czynnik humanistyczny uprawianego życia, potrzebna jest twórczość. Pisze Suchodolski: „Tylko twórczość [...] daje nam poczucie mocy” (Suchodolski 1936). W warunkach twórczego uprawiania życia działalność jest dobrem samym w sobie, zaś bliźnich traktujemy jako współuczestników. Tak rozumiana „pełnia życia” określana jest przez „możność twórczego istnienia” (Suchodolski 1936). Jednak ta „możność" nie może zaistnieć tam, „gdzie niesprawiedliwe stosunki społeczne i gospodarcze krzywdzą i ograniczają żywotność jednostek ludzkich, gdzie deprawujące instytucje i prawa niweczą możliwości życiowych zamierzeń [...]. Tam miłość zostaje wykrzywiona, a instynkty twórcze wynaturzone" (Suchodolski 1936).

\section{Poszukiwanie wartości czy ucieczka przed życiem?}

W wielkich społeczeństwach współczesnej cywilizacji pewne formy istnienia społecznego, prawa i instytucje stanowią niejednokrotnie poważną przeszkodę dla tak rozumianego, prawidłowego rozwoju moralnego, postępującego - przypominamy głównie przez samorozwój społeczny jednostki. Utrwalają one bowiem przemożnie uczucia wyższości i niższości, gwałtu i przemocy, wyzysku i nierówności, stając się „źródłem wewnętrznych powikłań rozwoju osobowego oraz, tym samym, powikłań współżycia” (Suchodolski 1936, s. 28). „Gdy cenimy pewne wartości, ale jesteśmy z jakichkolwiek względów zbyt słabi, żeby je osiągnąć, wówczas z przesadną gorliwością krzewimy kult wartości wręcz przeciwnych tamtym, nieosiągalnym" (Suchodolski 1936). Takie życie nie jest twórczym poszukiwaniem wartości, ale ma charakter ucieczki przed życiem. Pewne bowiem wartości ceni się nie ze względu na ich istotę, ale dlatego, że są „narzędziem ucieczki od innych” (Suchodolski 1936). Tak więc problem urzeczywistnienia prawdziwej funkcji wartości humanistycznych w nowoczesnych zbiorowościach mocno się komplikuje.

Stąd wywodzi się słabość i wręcz fałszywość wychowania moralno-społecznego ludzi młodych w czasach postępującej globalizacji, niosącej realną groźbę utraty głębokiej specyfiki wartości. Potrzebna byłaby bowiem taka „reforma życia dorosłych, by młodzież, wchodząc w życie, nie była nim deprawowana" (Suchodolski 1936, s. 29) ${ }^{4}$. Cel ten jest jednak nie do osiągnięcia - o czym była już mowa - przez przesunięcie wartości z dusz jednostek w świat społeczny i tam zwycięskie jej „rozegranie” dzięki nauce i organizacji. Funkcja wartości „bowiem na tym polega, by działać w duszach jednostek, a nie na tym, by uchodzić za wartość" (Suchodolski

4 Tak też sądził Florian Znaniecki, który swoje stanowisko wyraził Ludziach teraźniejszych (Znaniecki 1935, s. 310, 317, 317-318, 320, 321, 323-324). 
1936). Stąd waga procesów kreacji wartości. Warunkiem moralnej doniosłości takich procesów są akty przewyższenia wartości już istniejących $\mathrm{w}$ „obowiązującej” kulturze. I tylko uruchomienie takiego procesu daje prawo kształtowania osobowości kulturalnej. Wielką rolę ma w tym procesie charakter pracy podejmowanej przez człowieka. Jeśli praca nie odpowiada zdolnościom i zamiłowaniom, wówczas hamuje rozwój osobowości: „Wyczerpani taką pracą, szukamy rozrywki oszałamiającej, która by pozwoliła zapomnieć o sobie" (Suchodolski 1936).

\section{Wychowanie społeczno-moralne a pedagogika i pedagogia}

Stanowisko Bogdana Suchodolskiego w kwestii miejsca wychowania społeczno-moralnego w systemie wychowania - wykorzystujące twórczo poglądy Schelera, Sprangera i Hessena -należy do najwybitniejszych osiągnięć nowoczesnej myśli pedagogicznej. Zdaniem Suchodolskiego, wychowanie to nie zajmuje terenu swoistego, położonego obok wychowania religijnego, estetycznego, intelektualnego, fizycznego itd., moralność bowiem nie jest odrębnym terenem życia, ale jedną $\mathrm{z}$ form życia, które ujawniają swoje treści w warunkach konfliktu wartości, gdzie koniecznym staje się podjęcie przez jednostkę normatywnej decyzji wyrażającej charakter dokonywanego wyboru. Stąd wychowanie nie może opierać się na żadnej dydaktyce, lecz powinno mieć w swej podstawie opiekę prowadzoną w duchu miłości „zespalającej ucznia z nauczycielem i pobudzającej siły duchowe wychowanka” (Suchodolski 1936, s. 31). Opieka ta wyraża się troską o „rozwój w duszy wychowanka zdolności odczuwania i kształtowania wartości” (Suchodolski 1936). Treści $z$ różnych dziedzin, z którymi nauczyciel zapoznaje ucznia, stanowią tylko - ale aż tylko - materiał kształcenia formalnego, co ma właśnie rozwijać takie zdolności. W ten sposób odwodzimy proces wychowania od przedmiotowej zadaniowości, a koncentrujemy je wprost na pobudzaniu sił ucznia ku wartościowemu kulturalnie ich ujmowaniu. Powołując się na Hessena, Suchodolski wprost stwierdza, że jeśli ktoś chce być moralnym, nie może dążyć do moralności, „skoro bowiem stanie się ona jego świadomym zamiarem, przekształci się w faryzeuszostwo" (Suchodolski 1936). Moralność bowiem tkwi nie w intencyjnych treściach, lecz w sposobie spełniania konkretnych życiowych zadań. Prawo to dotyczy nie tylko moralności, ale również mądrości czy wrażliwości estetycznej. Nie stajemy się moralnymi, mądrymi, wrażliwymi estetycznie przez to, że tego chcemy, specjalnie starając się o to. Decyduje o tym charakter pracy, jaką wykonujemy (por. Suchodolski 1936, s. 32).

Omawiane prawo pedagogiczne dotyczy w równej mierze, jak w przypadku rozwoju życia wewnętrznego osobowości, kształtowania dobra społecznego (dóbr społecznych). Takiemu dobru „służy najgłębiej i najpewniej ten, kto w samej służbie odnajduje wartościową linię własnego życia, a nie ten, kto ją pełni dlatego, że jest 
wymagana, lub dlatego, iż jej rezultaty są korzystne" (Suchodolski 1936)5. Omawiany autor zwraca tu uwagę na szczególną doniosłość stosowania motywacji osobowej i rozwoju aktywności społecznej jako kryteriów moralno-społecznych w obliczu wyzwań: „Jedną z przyczyn jest niepokój światowy grożący zagładą cywilizacji i wymagający opanowania” (Suchodolski 1936). Potrzebna jest dziś odwaga jako wyraz godności osobistej oraz wrażliwość, która wymaga siły wyobraźni, „by przejąć się losem ludzi cierpiących z dala, może w innych częściach świata, a nie tylko losem spotkanego przypadkowo na ulicy żebraka" (Suchodolski 1936, s. 33) - pisał przenikliwie w roku 1936. „Najcenniejszym zaś darem jest inteligencja krytyczna i bystra, pozwalająca uwolnić się od przesądów i namiętności stadnych" (Suchodolski 1936).

\section{Wychowanie uczestniczące i reformujące}

Droga do tego ideału wiedzie przez wybraną i lubianą pracę, realizowaną w umiejętnie przebudowanych technicznych i społecznych warunkach. Chodzi w tym wymiarze o to, aby życie wewnętrzne ludzi nie było „rozłamane na znienawidzoną rzeczywistość dnia codziennego i na bezpłodne, nierealne albo szkodliwe kompensacje " (Suchodolski 1936, s. 43). Jednostki właśnie w życiu codziennym, a nie w jakichś specjalnych społeczno-moralnych zabiegach, winny znaleźć warunki dla rozwoju psychicznie zdrowego. W społeczeństwie moralnie zdrowym jednostki nie mogą być zmuszane do „życia według impulsów posiadania” (Suchodolski 1936). Przemożna bowiem tendencja do „nabywania i gromadzenia” (Suchodolski 1936) wygasza w ludziach konieczne dla prawidłowego rozwoju osobowości impulsy twórcze. Te ostatnie prowadzą do miłości życia, odwodząc od zakłamywania przez posiadanie i gromadzenie neurotycznie wytwarzanego poczucia własnej niemocy. Poprzez rozwój zdolności i chęci współpracy, a także współdziałania w realizacji własnych celów życiowych jednostka staje się moralnie zdrową. „Kto nie umie wyżywać się w tworzeniu, znajduje rozkosz w niszczeniu" (Suchodolski 1936, s. 44) - twierdzi Bogdan Suchodolski. Natomiast „pod względem intelektualnym wychowanie musi być oparte na prawdzie i szczerości, nawet w sprawach drażliwych. Wiara w siłę prawdy, niechęć do dogmatyzmu i sceptycyzmu są podstawą charakteru" (Suchodolski 1936). Tylko poprzez aktywne uczestnictwo w zmiennych warunkach życia i w próbach ustawicznych odpowiedzi na kolejne wyzwania, także wychowawcze, jednostka uczy się tworzyć w miarę stabilne warunki i umiejętności współżycia przez uczestnictwo ${ }^{6}$.

5 Dokładnie tę problematykę omawia B. Suchodolski w tekstach Droga do kultury (1936a) i O wielkości człowieka (1936b). Tekst Droga do kultury można też znaleźć w pierwszym i drugim wydaniach Uspołecznienia kultury (1937, s. 11-16; 1947, s. 89-94). Tekst drugi wyłącznie w wydaniu drugim Uspołecznienia... (1947, s. 139-143).

6 Problem ten naświetlił B. Suchodolski w tekście O prawdzie (1947b). 
Podstawowym walorem wychowania uczestniczącego jest - zdaniem Suchodolskiego - prawidłowość pedagogiczna mówiąca, iż „kształcić się bowiem można tylko na tych treściach, które stanowią dla nas przedmiot zainteresowań i działań aktualnych, informacje zaś i nakazy, dotyczące rzeczy, do których «nie dorośliśmy» jeszcze, nie mają siły wychowawczej, choćby nawet były pozornie przyswojone" (Suchodolski 1936, s. 45). Dlaczego? Ponieważ wychowanie jest tak naprawdę samowychowaniem postępującym poprzez tworzenie warunków rozwoju indywidualnego, społecznego i kulturalnego w trakcie całego życia człowieka. Tak więc stanowisko edukacyjne, założone w wychowaniu przygotowującym, zakładającym, że życie ludzkie można podzielić na „okres przygotowania i okres użytkowania" (Suchodolski 1936), jest błędne. Ponieważ człowiek wciąż wchodzi w nowe sytuacje, może i powinien kształcić się przez całe życie. W ten sposób idea wychowania uczestniczącego staje się ważnym źródłem koncepcji kształcenia permanentnego. Stąd oczywiste w wychowaniu przygotowującym „udzielanie wiedzy na zapas, na wyrost, jest hołdowaniem werbalizmowi, który nie posiada żadnej siły wychowującej, a rodzi się z niesłusznej obawy, by nie odkładać niczego na później” (Suchodolski 1936, s. 46). Takie „udzielanie wiedzy” musi być przezwyciężone przez wychowanie reformujące. Czynne uczestnictwo w wartościach życia przy warunkach cywilizacji zmiennej oznacza aktywne, permanentne reformowanie procesów samokształcenia i samowychowania.

Tworzenie w takim wychowaniu prowadzi do powstawania jakości niedających się społecznie sprowadzić do tego, co już było. Analizowany autor pisze: „Tam [...], gdzie się tworzy nową kulturę, postawa dorosłych nie może być filisterska [...]. To właśnie zespala młodzież i ludzi dojrzałych" (Suchodolski 1936). Szczerość, brak obłudy są tu najważniejsze, nawet jeśli nie możemy przesądzić, czy określona rzeczywistość powinna się zmienić, czy pozostać niezmienioną. „Granica budzenia niechęci do istniejącego porządku powinna przebiegać zależnie od możliwości wykonawczych. W określaniu tych możliwości zdarzyć się mogą omyłki, ale nie powinno to oznaczać, iż wychowawca ma się wyzbyć wyczucia czasów idących. Jest to najgłębsza i najbardziej twórcza cecha wychowawcy" (Suchodolski 1936, s. 51).

Tego rodzaju konstatacja współczesności stała się u Suchodolskiego zarzewiem krytyki liberalizmu?. Suchodolski dostrzega w filozofii liberalizmu wiele pozytywnych stron. Jednak równocześnie zwraca szczególną uwagę na groźne niebezpieczeństwo popadnięcia w indywidualistyczny hedonizm, czemu sprzyja

7 Bardzo ważna jest tu późna praca B. Suchodolskiego Wychowanie i strategia życia (1983). Jeśli weźmiemy w nawias większość zawartych tam „socjalizmów” (termin ten nie jest u Suchodolskiego marksistowski, raczej przypomina „cywilizację nowego typu” w Ludziach teraźniejszych... Floriana Znanieckiego [2001]), wówczas w całej pełni ukaże się nam głęboko humanistyczne, antysystemowe stanowisko autora Skąd i dokąd idziemy (Suchodolski 1999, Warszawskie Wydawnictwo Literackie MUZA SA, Warszawa - praca ta nie była cytowana w niniejszym artykule, nie znajduje się w bibliografii). 
właśnie kształtowanie życia ludzkiego zależnie od układu interesów, przy zupełnym lekceważeniu zarówno religijnych, jak i humanistycznych wartości trwałych.

\section{Kształcenie społeczno-moralne jako samowychowanie humanistyczne}

Gdy więc na nowo postawimy problemat samowychowania społeczno-moralnego, musimy dojść do wniosku, iż konstytutywnym warunkiem powstawania i rozwoju osobowości jest wspólnota. Równocześnie też zauważamy, że powstawanie i rozwój osobowości stanowi warunek niezbędny istnienia wspólnoty i społeczno-moralnego jej kształtu. Tak więc - pisze Suchodolski - „wspólnota nie jest tylko tradycyjną i nienowoczesną formą życia, ale jest stałą kategorią psychiki ludzkiej, nie jest w stosunku do jednostki jedynie zespołem więzów krępujących i ograniczających, ale ma również doniosłe znaczenie, pobudzające i harmonizujące osobowość jednostki. Powstaje wówczas poczucie trwałości i ważności pewnego wspólnego typu życia" (Suchodolski 1936, s. 53). Podkreślić tu trzeba zbawienną moc stałej i wiernej orientacji na trwałe wartości humanistyczne, przecież zawsze krytycznej zarówno wobec rzeczywistości totalistycznego państwa, indywidualistycznej samowoli, jak i także wobec dogmatyzacji wartości powszechnie uznanych za „trwałe”. Suchodolski podkreśla, że najgłębsza i najbardziej wartościowa postawa wobec rzeczywistości wyraża się w uczuciach i działaniach. Tak też jest z ludzką moralnością, która nie polega na zgodności czynów z jakimiś wymyślonymi zasadami, ale na konkretnym działaniu w konkretnym środowisku społecznym. Jednak twierdzenie, że kulturę żywą reprezentującą w pełni określenie definicyjne tego pojęcia może - w połowie XX wieku - stanowić wspólnota pojmowana jako bezwzględna służba interesom państwowym, nie jest prawdziwe i nie daje się obronić.

Stąd wynika dokonana przez Suchodolskiego druzgocąca ocena idei faszyzmu i socjalizmu narodowego z punktu widzenia humanizmu. Zgadzając się z faszyzmem w dziedzinie krytyki naturalizmu, Suchodolski zdecydowanie przeciwstawia się wnioskom, które przez faszyzm i narodowy socjalizm z tej krytyki zostają wyprowadzone. Wartość tej postawy, ujawnionej w taki sposób w roku 1936, mimo wielu historycznych meandrów i zawirowań, obroni się, gdy zostanie dokonana analiza całego jego dorobku piśmienniczego, począwszy od tekstu Pokrewieństwo poglądów Cieszkowskiego, Trentowskiego i Euckena z roku 1923 aż po pośmiertnie wydaną w roku 2003 książkę Edukacja permanentna (francuski tytuł oryginału: Education permanente en profondeur). Jej skrótowym opisem niech będzie poniższy cytat: „Humanizm, jako prąd społeczno-kulturalny, zgodny z tamtymi w negacji naturalizmu społecznego, odsłania pozytywne horyzonty [...] rozległe. Ponad potrzebami konkretnego życia narodowego w pewnej epoce i w pewnym układzie stosunków istnieją ogólnoludzkie wartości i normy moralne. [...] Poza podniecającą atmosferą gromady znajduje się miejsce na osobiste przeżycie sprawy moralnej, jako własnego losu, własnej odpowiedzialności, własnego obowiązku. [...] Ład moralny nie jest refleksem interesów narodowych, ale istotą i powołaniem 
człowieka. Porządek społeczny nie jest narzędziem siły w rękach rządzących klas, ale realizacją warunków ludzkiego życia dla każdego" (Suchodolski 1936, s. 58).

\section{Praca a praca ludzka}

Powyższy wywód, mający kardynalne znaczenie dla rozumienia, dlaczego nie można po prostu nauczać moralności oraz jaka jest właściwa droga ku znaczącej i ustawicznej poprawie jakości moralnej człowieka, w całej swej rozciągłości odnosi się również do zagadnienia pracy. Zgadzając się tu ze stanowiskiem Brzozowskiego, Suchodolski stwierdza, iż „praca jest zasadniczą cechą człowieczeństwa. Ma charakter konkretny, a zarazem powszechny” (Suchodolski 1936).

Lecz nie każda praca ma wymiar humanistyczny i przez to może stawać się "pracą ludzką”. I tak, ocena pracy „ze stanowiska człowieka” (Suchodolski 1936, s. 62), pozwala określać, czy dana ideologia, uzasadniająca „ludzkość” pracy, jest w istocie słuszna. Humanista dobitnie stwierdza, że tzw. światopogląd pracy nie może określić całokształtu bytu człowieka i pełni jego psychiki. Dlatego „wywyższenie pracy ponad wszelkie inne formy działalności ludzkiej jest zazwyczaj owocem imperializmu wobec świata i utylitaryzmu wobec człowieka" (Suchodolski 1936). Ogromna większość procesów społeczno-moralnych przybiera wówczas postać dążeń socjalnych, co w żadnym razie nie rozwija człowieka jako istoty w pełni ludzkiej. Suchodolski cytuje tu Znanieckiego: „Człowiek pracy nie dba o obiektywne dążności twórcze, o swobodną twórczość; zależy mu na wyrobieniu dążności związanych z utrzymaniem lub poprawą stanu socjalnego, co można uczynić przez zarobek" (Suchodolski 1936, s. 63).

Wychowanie moralno-społeczne przez pracę możliwe jest tylko w warunkach „pracy biorytmicznej” (Suchodolski 1936, s. 64). Kreacja i rozwój społeczno-moralny prowadzą przez wychowywanie takich potrzeb, jak: „troska o pogłębienie wewnętrzne, umiłowanie przyrody, instynkt twórczy, kontemplacja, umiłowanie bliźnich jako ludzi” (Suchodolski 1936).

\section{Wymiana przeżyć, twórcze uczestnictwo, selekcja i kontemplacja}

Trzeba bowiem w tym dziele objąć całego człowieka. Bogdan Suchodolski z mocą podkreśli, iż „społeczna wartość człowieka polega na umiejętności uczestniczenia w wymianie przeżyć" (podkr. B.S.) (Suchodolski 1936), i tylko ta droga prowadzi go do rozwoju we wszystkich zakresach ludzkich wartości. Dopiero "plan życiowy”, który rodzi się „w głębi jednostkowego sumienia, odczuwającego odpowiedzialność za życie własne, raz jeden nam dane i tylko nasze" (Suchodolski 1936), rzutowany na środowisko otaczające nas i przekształcany tak, aby można było go realizować przy konkretnych uwarunkowaniach, staje się - również w wymiarze moralno-społecznym - znaczącym czynnikiem stosunku jednostki równocześnie do siebie samej, jak i do innych ludzi oraz innych składowych węziej i szerzej ujmowanego 
środowiska ludzkiego działania. We współczesnych warunkach „cywilizacji zmiennej” (Suchodolski 1936, s. 65) społeczno-moralna wartość tkwić może w samym procesie przemian. Jeżeli tak, to konieczny w tworzeniu optymalnych warunków rozwoju społeczno-moralnego ludzi determinowanych właściwościami cywilizacji zmiennej jest sojusz humanizmu z pragmatyzmem. W takim sojuszu - pisze Suchodolski - „wychowanie moralno-społeczne jest więc zaprawianiem do twórczego uczestnictwa (podkr. B.S.) w potoku życia, do współdziałania $\mathrm{z}$ innymi i do wydobywania $\mathrm{z}$ siebie nieznanych jeszcze w chwili bieżącej możliwości” (Suchodolski 1936, s. 66). Probierz owego wzrostu w dziedzinie społeczno-moralnej widzi Suchodolski w postawie człowieka wobec kultury duchowej. Wychowanie może i powinno odpowiedzieć na podstawowe zagrożenia powodowane „tempem życia i przerostem ekonomicznego punktu widzenia" (podkr. B.S.) (Suchodolski 1936, s. 67), kształtowaniem u ludzi postaw i umiejętności selekcji i kontemplacji. „Selekcja też jedynie umożliwia kontemplację” (podkr. B.S.) (Suchodolski 1936). Suchodolski wprowadza tutaj nowatorsko specyficzne rozumienie kontemplacji w warunkach cywilizacji zmiennej i zagrażającej. Pisze: „Słowo to, do niedawna niemodne, odzyskuje swoją wartość. Nie jest ono symbolem ucieczki od życia, klasztornej ascezy, nastrojowego subiektywizmu. Kontemplacja jest w gruncie rzeczy formą okazywania szacunku sobie samemu, ludziom, wartościom. Dlatego wytworzenie zdolności kontemplacyjnych u młodzieży zaliczone być musi do ważnych zadań wychowania moralno- społecznego, [...] przelotność i dorywczość są przyczynami obniżenia poziomu życia intelektualnego i życia uczuciowego" (Suchodolski 1936, s. 67-68).

\section{Współdziałanie humanistyczne}

Współcześnie niezwykle ważna w rozwoju społeczno-moralnym ludzi, odpowiednia w warunkach cywilizacji zmiennej, jest ich szczególna postawa wobec kultury materialnej - słowem, wobec tego, co dawniej i teraz człowiek stworzył i wytworzył w świecie przedmiotów. Cechować powinny ją: dążność do utrwalenia właściwej i krytycznej oceny wartości materialnych w kontekście całości nowoczesnego życia i jego dwu podstawowych zagrożeń, jakimi są tempo życia i przerost ekonomicznego punktu widzenia; wytworzenie przekonania, że procesy gospodarcze są plastyczne, ulegają ludzkim zamierzeniom; uwydatnienie w poglądach na organizację życia gospodarczego znaczenia jej „funkcji społecznej” (Suchodolski 1936, s. 69). Społeczno-moralnym wymiarem funkcji społecznej życia gospodarczego jest zarówno to, iż „ludzie nie powinni być traktowani jako rynek zbytu, w który wtłoczyć można wszelką ilość wszelkich produktów, byle z zyskiem" (Suchodolski 1936, s. 68), jak i dokonywanie podstawowej, humanistycznej zmiany charakteru samej pracy oraz jej roli w życiu. Pisze Suchodolski: „Tylko taka praca winna znajdować uznanie, która może wytworzyć dla pracowników środowisko wychowawcze, w którym mogą oni wzrastać jako ludzie" (Suchodolski 1936). 
Istotna w życiu, pracy, w których odbywa się rozwój moralny człowieka, jest „umiejętność współdziałania” (Suchodolski 1936, s. 70). Ale nie chodzi tu o zawieranie kompromisów na gruncie rzeczywistości niezmienionej. W warunkach cywilizacji zmiennej konieczne jest tworzenie nowych, wyższych płaszczyzn porozumienia, tak więc wszelkie „uzgadnianie wymaga twórczości” (Suchodolski 1936). Oznacza to, że umiejętność współdziałania nie może rozwijać się w życiu adaptacyjnym.

\section{Instytucje polityczne i wolność moralna}

W warunkach humanistycznej organizacji pracy miarą wzrostu gospodarczego jest rozwój człowieka jako jednostki samodzielnej opiekuńczo, edukacyjnie i wychowawczo, co oznacza, iż właśnie taki rozwój jest właściwym motorem pozytywnych osiągnięć gospodarczo-społecznych. „Prawa i instytucje powinny być takie konstatuje Suchodolski - by człowiek nie deprawował się, żyjąc wśród nich, ale by spełniając ich wymagania, służył zarazem własnemu rozwojowi” (Suchodolski 1936). W tej kwestii nie sposób rozstrzygnąć, jaki ustrój polityczny mógłby temu najlepiej służyć: „nie ma idealnych ustrojów politycznych” (Suchodolski 1936). W tym zakresie zadaniem wychowania moralno-społecznego jest wytwarzanie postaw i umiejętności dokonywania „stosownej przebudowy społeczno-politycznej, pozwalającej oceniać to, co jest złe, i to, co jest dobre w dzisiejszym życiu i organizacji” (Suchodolski 1936). Trzeba tu znajdować twórcze porozumienie pomiędzy roszczeniami a ofiarnością.

Należy pedagogicznie doprowadzać do takiego poziomu rozwoju społeczno-moralnego, aby ani roszczenia, ani ofiarność nie wynikały z przymusu, a właśnie z powinności mającej u swej podstawy wolność moralną. Inaczej człowiek „ma duszę niewolniczą" (Suchodolski 1936, s. 71).

Podstawowym zagrożeniem dla możliwości urzeczywistniania tego typu procesów pełnego rozwoju społeczno-moralnego jest gospodarczo-techniczny charakter obecnej cywilizacji. „Pod wpływem czynników gospodarczo-technicznych powstaje mniemanie, iż jednostka osiąga całkowicie swą pełnię oraz wykonywa wszystkie wobec siebie zobowiązania przez swe uczestnictwo w zorganizowanym procesie wytwórczym życia zbiorowego" (Suchodolski 1936). Mniemanie to jest z gruntu fałszywe. „Wynikiem tego stanu rzeczy jest wielka liczba ludzi spełniających dzielnie swe obowiązki zawodowe i społeczne, a jednocześnie żyjących poza sferą tych obowiązków, bardzo powierzchownie i poziomo. Taka wewnętrzna dwoistość jest jednak na dalszą metę deprawująca" (Suchodolski 1936). Osiągnięcie takich celów społeczno-moralnych jest zdaniem Suchodolskiego niezwykle trudne. Wymaga bowiem takiego przekształcenia warunków życiowych, aby pogłębiła się i rozszerzyła świadomość, „że to, co robimy ze sobą w chwilach swobody, ma doniosłe znaczenie społeczne" (Suchodolski 1936). I ważne, aby ta zasada stała się wytyczną wychowania rozumianego równocześnie jako wychowanie siebie samego. 


\section{Stosunek do kształcenia i humanistyczna samorządność jednostki}

Kolejną istotną kwestią jest stosunek do oświaty. Stoi on w zupełnym przeciwstawieniu do postawy sarkastycznie ujętej przez profesora: „Wydaje się człowiekowi, iż skoro wstanie od książki, żyć już może jakkolwiek i nie jest obowiązany dbać o swe pogłębienie, stykając się bądź to z przyrodą, bądź to ze sztuką, bądź to z ludźmi” (Suchodolski 1936, s. 72). Rozwój osobowości dokonuje się bowiem przez całą życiową postawę człowieka, a nie tylko przez oficjalną i niejako „zewnętrzną” oświatę. Jakie wobec tego wszystkiego mogłyby być zadania wychowawcy? Trzeba zdecydowanie odejść od przedmiotowego, szkolarskiego, oświatowego traktowania kwestii społeczno-moralnych. Zamiast tego Suchodolski proponuje szczere i śmiałe podejmowanie zagadnień aktualnych, pobudzanie do zadań ważnych i porywających, budowanie wspólnoty odpowiedzialnego trudu, wymagającego dyscypliny koniecznej dla realizacji zadania, a nie będącej elementem zewnętrznego, niejako instytucjonalnego przymusu. Skuteczność wpływu wychowawcy zależy od tego, czy staje się on czynnikiem zaspokajania i wręcz realizowania "planu życiowego" danego człowieka lub społeczności.

Przeciwstawia się jednak Suchodolski popularnym w pedagogice hasłom „przygotowania do życia”, skazującym jednostkę nie tylko na uzależnienie od oświaty, ale również czyniącym ją osobą żyjącą przede wszystkim w nurtach zabezpieczających, reaktywnie i zapobiegliwie dostosowawczo. Uważa, że kluczem w tej sprawie może być znalezienie właściwej interpretacji tradycji - w sposób, który sprzyjałby łagodzeniu sporów i rozbieżności. „Dopiero na tle tych wielkich zagadnień kształtowania duszy zbiorowej w przełomowej epoce mogą być w sposób właściwy postawione i rozwiązywane konkretne sprawy wychowania młodzieży" (Suchodolski 1936). Taka jest hierarchia ważności spraw i taka jest kolejność postępowania pedagogicznego. „Taka jest zresztą struktura życia: czy chcemy, czy nie, wyminąć nie potrafimy wielkich zadań, jakie stoją przed nami. Ucieczka w drobiazgowość codziennej szarej pracy jest także liczona przez Los jako odpowiedź. Ale jako odpowiedź zła” (Suchodolski 1936).

\section{Bibliografia}

Suchodolski B. (1935), Nowy humanizm. „Miesięcznik Literatury i Sztuki”, nr 8, S. 232-240.

Suchodolski B. (1936). Wychowanie moralno-społeczne, Warszawa: Nasza Księgarnia - Spółka Akcyjna Związku Nauczycielstwa Polskiego.

Suchodolski B. (1936a). Droga do kultury. „Polska Zbrojna”, nr 142. Opublikowany również w: B. Suchodolski (1947). Uspołecznienie kultury, s. 89-94

Suchodolski B. (1936b). O wielkości człowieka. „Polska Zbrojna”, nr 101. Opublikowany również w: B. Suchodolski (1947). Uspołecznienie kultury, s. 139-143. 
Suchodolski B. (1937). Uspołecznienie kultury. Warszawa: Towarzystwo Wydawnicze „Rój”.

Suchodolski B. (1947a). Uspołecznienie kultury. Warszawa: Trzaska, Evert i Michalski. Suchodolski B. (1947b). O prawdzie. „Znak”, nr 4, s. 390-409

Suchodolski B. (1983). Wychowanie i strategia życia. Warszawa: WSiP.

Suchodolski B. (2005) O prawdzie. „Teraźniejszość-Człowiek-Edukacja”, nr 1, s. 7-19

Znaniecki F. (2001). Ludzie teraźniejsi a cywilizacja przyszłości. Warszawa:

Wydawnictwo Naukowe PWN.

\title{
CRITIQUE AS A POSITIVE MOMENT OF HUMAN UPBRINGING IN THE HUMANISTIC CONCEPT OF MORAL AND ETHICAL INSTRUCTION OF BODGAN SUCHODOLSKI
}

\begin{abstract}
In the book The Morally-Social Education (1936) by Bogdan Suchodolski the idea and practice of traditional morally-social education has been subjected to a profound critical examination. The morally-social development refers to human personality on the whole and it grows and changes throughout our whole life. Therefore, education should not be limited to some sort of "educational time" in contradiction to/as opposed to a "life time" nor should it be separated from an individual's environmental changes both in close and remote perspective. In this context Suchodolski proves the uselessness of preparatory education emphasizing the significance of participating and reforming education. Thus, the morally-social education should consist in the kind of personal education which enables her/him to achieve independence in self-education and through development of the inner-self, social and cultural life abilities. This is achieved not in the intellectual way, but integrally, by surpassing the level of hitherto progress through love and creativity in establishing/developing a community. This is due to the nature of personal work which leads to inner development of personality and socializing participation in the surrounding reality.
\end{abstract}

Keywords: personality, morally-social education meant as humanistic self-education, love, human work, exchange of experiences, community throughout creating participation, selection and contemplation, moral independence.

Andrzej Sztylka - doktor nauk humanistycznych w zakresie pedagogiki, uczeń Profesor Ireny Wojnar i Profesora Bogdana Suchodolskiego. Założyciel i prowadzący klubu Humanistyczna Filozofia i Sztuka Życia w Staromiejskim Domu Kultury w Warszawie (1990-2013). W latach 1995-2001 członek Stowarzyszenia Oświatowców Polskich. W latach 1990-2002 wiceprezes zarządu Stowarzyszenia SOS Wioski Dziecięce w Polsce. Członek Towarzystwa Pedagogiki Filozoficznej im. B. Trentowskiego, członek Kapituły Medalu im. B. Trentowskiego. Publikacje autorskie: Jak stawać się Humanista (1999) i Podstawy humanistycznej sztuki życia (2008). Adres mejlowy: andrzej.sztylka@gmail.com. 